\title{
PENGARUH PENGGUNAAN MODUL TERHADAP PRESTASI \\ BELAJAR SISWA PADA MATA PELAJARAN AKUNTANSI KELAS XI
}

\section{IPS}

\author{
Wahyu Wulansari \\ SMK Bhakti Mulia Kediri \\ wahyuwulansari@yahoo.com
}

\begin{abstract}
The purpose of this study is to observe the effect of the module on student achievement in accounting subjects. The research design is quasi experiment by using Nonequivalent Control Group Design. Sampling was done by purposive sampling technique. The sample set consists of two classes of XI IPS 3 as the experimental group and XI IPS 4 as a control group. The result of this study indicates that there is the effect of the use of the module on student achievement. As the experiment is conducted only in one competence, it is suggested that other researchers might conduct research on the use of modules in more than one competence by adding the time of the research so that effectiveness of the use of modules to enhance student achievement can be attained.
\end{abstract}

Keywords: Modul, Accounting, Student Achievement

\begin{abstract}
Abstrak: Tujuan penelitian ini adalah untuk mengetahui pengaruh penggunaan modul terhadap prestasi belajar siswa dalam mata pelajaran akuntansi. Rancangan penelitian yang digunakan adalah quasi eksperimen dengan menggunakan desain nonequivalent control group. Pengambilan sampel dilakukan dengan teknik Purposive Sampling. Sampel yang ditetapkan terdiri dari dua kelas yaitu kelas XI IPS 3 sebagai kelompok eksperimen dan kelas XI IPS 4 sebagai kelompok kontrol. Hasil penelitian menunjukkan bahwa terdapat pengaruh dari penggunaan modul terhadap prestasi belajar siswa. Adapun keterbatasan dari penelitian ini adalah penelitian hanya dilakukan pada satu pokok bahasan saja dikarenakan adanya keterbatasan waktu penelitian. Oleh karena itu disarankan agar peneliti lain dapat melakukan penelitian tentang penggunaan modul pada materi lain atau lebih dari satu pokok bahasan dengan menambah waktu penelitian sehingga dapat diketahui keefektifan penggunaan modul untuk meningkatkan prestasi belajar siswa.
\end{abstract}

Kata Kunci: Modul, Akuntansi, Prestasi Belajar

Pengembangan sumber daya manusia melalui pendidikan harus diperhatikan dengan sungguh-sungguh karena pendidikan berperan penting dalam usaha pembentukan generasi penerus dan menciptakan sumber daya manusia yang berkualitas, sehingga dapat bersaing secara global. Oleh karena itu yang harus dipikirkan adalah mengupayakan agar sebagian besar siswa dapat belajar secara efektif dan mampu menjadi pribadi yang tangguh bagi perkembangan selanjutnya dalam masyarakat yang semakin hari semakin kompleks. 
Dalam proses belajar di sekolah, pemilihan dan penggunaan strategi yang tepat juga menjadi salah satu bagian terpenting bagi keberhasilan proses penyampaian ide-ide pembelajaran dari guru kepada siswanya. Salah satu usaha yang dapat digunakan guru untuk mengaktifkan siswa dalam proses pembelajaran adalah sistem belajar dengan modul.

Sistem belajar dengan modul merupakan suatu cara penyampaian ide atau gagasan kepada siswa dengan menggunakan media modul. Modul yang telah disusun selanjutnya digunakan untuk memberikan materi kepada siswa. Pembelajaran modul termasuk salah satu sistem pembelajaran individual, sebab belajar dengan modul menuntut siswa untuk belajar mandiri. Mulyasa (2002:43) menjelaskan bahwa tujuan utama sistem modul adalah untuk meningkatkan efisiensi dan efektivitas pembelajaran di sekolah, baik dari segi waktu, dana, fasilitas, maupun tenaga guna mencapai tujuan secara optimal. Mengingat kemampuan setiap individu itu berbeda-beda sehingga untuk mencapai hasil belajar yang baik maka cara mengajarnya disesuaikan dengan kemampuan masing-masing siswa. Hal ini sesuai dengan pernyataan Mbulu (2001:89) bahwa pengajaran modul memberikan kesempatan kepada siswa yang berbeda-beda untuk memecahkan masalah tertentu berdasarkan latar belakang pengetahuan dan kebiasaan masing-masing (Mbulu, 2001:89).

Meskipun metode pengajaran individual banyak ragamnya namun salah satu yang paling menonjol adalah pengajaran dengan modul. Pengajaran dengan modul termasuk metode yang menggabungkan keuntungan-keuntungan dari berbagai pengajaran individual lainnya seperti tujuan instruksional khusus, belajar menurut kecepatan masing-masing, dan balikan atau feedback yang banyak. Suatu modul adalah suatu unit yang lengkap yang berdiri sendiri yang terdiri dari suatu rangkaian kegiatan belajar yang disusun untuk membantu siswa mencapai sejumlah tujuan yang dirumuskan secara khusus dan jelas (Nasution, 1992:204205).

Mbulu (2001:90) menyatakan bahwa modul dapat mengandung berbagai macam kegiatan-kegiatan belajar seperti membaca buku pelajaran atau karangankarangan, memperhatikan gambar atau foto serta diagram, melihat film atau slide, mendengarkan audio-tape, menyelidiki berbagai alat demonstrasi serta dalam 
proyek dan eksperimen. Dengan menggunakan modul, siswa dapat belajar secara mandiri tanpa tergantung pada teman serta dapat belajar sesuai dengan kemampuannya.

Ciri-ciri pembelajaran modul sebagaimana yang dipaparkan oleh Vembriarto (1975:35) adalah: (1) modul merupakan paket pembelajaran yang bersifat self instruction; (2) pengakuan atas perbedaan-perbedaan individual; (3) memuat rumusan tujuan pengajaran secara eksplisit; (4) adanya asosiasi, struktur dan urutan pengetahuan yang ditunjukkan dengan adanya gambar atau penjelasan dan kegiatan yang bisa dilihat ataupun dilakukan siswa sendiri secara langsung dengan materi yang sudah disusun sesuai dengan struktur pengetahuan secara hirearkis; (5) penggunaan berbagai macam media; (6) partisipasi aktif siswa; (7) adanya reinforcement langsung terhadap respon siswa; dan (8) adanya evaluasi terhadap penguasaan siswa atas hasil belajarnya.

Pelaksanaan pengajaran dengan modul menurut Setyosari (1991:17-18) bagi yang sudah biasa melaksanakan yaitu guru langsung saja membagikan modul kepada siswa yang kemudian siswa bekerja sendiri. Guru memberi petunjukpetunjuk kepada siswa apabila diperlukan. Siswa yang cepat menyelesaikan modul langsung diberi tugas pengayaan atau pengembangan. Sedangkan siswa yang lambat mengerjakan modul diberi tambahan waktu untuk menyelesaikan modul yang menjadi tanggung jawabnya atau diberi bantuan khusus untuk memecahkan kesulitan yang dihadapi yang tidak dapat diselesaikan tepat pada waktunya. Dengan demikian, cara belajar melalui penggunaan modul memberi kesempatan seluas-luasnya kepada siswa untuk terlibat dalam tugas, sehingga hasil belajar yang dicapai oleh siswa benar-benar merupakan usahanya sendiri.

Tugas guru dalam pengajaran modul bukan lagi sebagai pemberi informasi seperti pada pengajaran konvensional, tetapi tugas guru sebagai pengelola kegiatan belajar mengajar. Guru mengawasi kegiatan belajar mengajar agar para siswa dapat belajar secara tepat sekaligus memberi bimbingan kepada mereka yang mengalami hambatan atau kesulitan. Di pihak lain, bagi siswa diharuskan mempelajari petunjuk atau pedoman siswa secara cermat sehingga tiap langkah yang harus dilakukan tidak lagi menjadi hambatan baginya untuk menyelesaikan modul tepat pada waktunya. Dengan mempelajari petunjuk tertulis tersebut siswa 
akan terdorong untuk berkreasi melakukan tugas-tugasnya sesuai dengan maksud dan tujuan modul itu sendiri.

Prestasi belajar merupakan suatu hasil yang diperoleh setelah siswa mengalami dan melaksanakan proses belajar. Rendahnya prestasi belajar siswa dapat dipengaruhi oleh kurangnya ketersediaan sarana dan prasarana belajar, terlebih adalah ketersediaan buku penunjang bahan pelajaran. Selain itu, rendahnya prestasi belajar mungkin dipengaruhi juga oleh aktivitas dan kemandirian belajarnya. Kebanyakan siswa hanya belajar apabila di sekolah saja padahal akuntansi merupakan mata pelajaran yang membutuhkan banyak latihan dan keterampilan. Oleh karena itu, anak mungkin perlu untuk sedikit dipaksa agar dapat belajar dengan rutin di rumah. Dengan adanya modul diharapkan dapat mendorong siswa untuk belajar di rumah agar materi yang disampaikan di sekolah tidak mudah dilupakan dan lebih menjadikan anak memahami pelajaran.

Berdasarkan hasil observasi dan wawancara dengan guru mata pelajaran akuntansi yang dilakukan di SMA Negeri 6 Malang pada semester ganjil tahun ajaran 2010/2011 dapat diketahui bahwa kegiatan pembelajaran di SMA Negeri 6 Malang cenderung menggunakan pembelajaran secara konvensional yang didominasi oleh ceramah dan penugasan. Di SMA Negeri 6 Malang terdapat sumber belajar berupa buku paket atau buku penunjang mata pelajaran akuntansi tetapi hanya bisa dipakai pada saat jam pelajaran saja (tidak dibawa pulang). Setelah jam pelajaran selesai, buku dikembalikan ke perpustakaan. Sumber belajar yang lain seperti Lembar Kegiatan Siswa (LKS) untuk semester ganjil pada saat dilakukan penelitian tidak ada, oleh karena itu siswa kesulitan untuk belajar sendiri di rumah dan mengerjakan tugas rumah, sehingga nilai ulangan harian atau tugas masih di bawah Standar Ketuntasan Minimal (SKM).

Berdasarkan latar belakang di atas, maka akan menarik untuk mengetahui efek penggunaan modul terhadap prestasi belajar siswa dalam penelitian yang berjudul "Pentingnya Modul terhadap Prestasi Belajar Siswa dalam Mata Pelajaran Akuntansi Kelas XI IPS”. 


\section{METODE}

Rancangan penelitian ini menggunakan penelitian quasi eksperimen dengan desain Nonequivalent Control Group. Penelitian ini membagi sasaran penelitian menjadi dua kelompok sampel, yaitu kelompok kontrol dan kelompok eksperimen. Kelompok kontrol adalah siswa yang tidak menggunakan modul dalam pembelajaran dan kegiatan pembelajaran dibiarkan berjalan seperti biasa. Sedangkan kelompok eksperimen adalah siswa yang menggunakan modul dalam kegiatan pembelajaran. Populasi dalam penelitian ini adalah seluruh siswa kelas XI IPS SMA Negeri 6 Malang tahun pelajaran 2010/2011 dengan jumlah 185 siswa yang terbagi dalam 5 kelas. Pengambilan sampel menggunakan teknik purposive sampling yaitu sampel dipilih tidak secara random tetapi sejak awal ditentukan oleh peneliti. Sampel yang ditetapkan terdiri dari 2 kelas, yaitu kelas XI IPS 3 yang berjumlah 34 siswa sebagai kelompok eksperimen dan kelas XI IPS 4 yang berjumlah 34 siswa sebagai kelompok kontrol. Adapun rancangan penelitiannya dapat dilihat pada gambar berikut.

\begin{tabular}{ccc}
$\mathrm{O}_{1}$ & $\mathrm{X}$ & $\mathrm{O}_{2}$ \\
\hline $\mathrm{O}_{3}$ & & $\mathrm{O}_{4}$
\end{tabular}

\section{Gambar 1. Rancangan Penelitian}

Teknik pengumpulan data dalam penelitian ini diperoleh melalui: (1) tes; (2) observasi; dan (3) dokumentasi. Tes digunakan untuk mengetahui keberhasilan pembelajaran dengan menggunakan modul dan pembelajaran tanpa menggunakan modul (konvensional) dalam materi jurnal penyesuaian. Tes ini terdiri dari 20 butir soal. Bentuk tes prestasi adalah tes objektif. Observasi dilakukan dengan menggunakan rubrik untuk mengukur aspek sikap siswa. Penilaian aspek sikap meliputi tanggungjawab individu, kerajinan, kejujuran, keaktifan bertanya dan kedisiplinan. Selain itu digunakan lembar observasi sebagai lembar pengamatan yang berisi tentang penilaian kegiatan belajar yang menggunakan modul. Analisis data dilakukan dengan Independent Sample T-Test. 


\section{HASIL DAN PEMBAHASAN}

\section{Hasil}

Tabel 1 menunjukkan data kemampuan awal kelompok eksperiment. Siswa yang mendapat kriteria baik sekali adalah 1 siswa dengan prosentase 2,94\%, 3 siswa mendapat kriteria baik dengan prosentase 8,82\%, 11 siswa mendapat kriteria cukup dengan prosentase 32,35\%, 15 siswa mendapat kriteria kurang dengan prosentase $44,12 \%$, dan 4 siswa mendapat kriteria kurang sekali dengan prosentase $11,76 \%$.

Tabel 1. Deskripsi data kemampuan awal kelompok eksperimen

\begin{tabular}{lllll}
\hline No. & Kriteria & Interval & Frekuensi & Prosentase \\
\hline 1. & Baik sekali & $89-100$ & 1 & $2,94 \%$ \\
2. & Baik & $78-88$ & 3 & $8,82 \%$ \\
3. & Cukup & $67-77$ & 11 & $32,35 \%$ \\
4. & Kurang & $56-66$ & 15 & $44,12 \%$ \\
5. & Kurang sekali & $45-55$ & 4 & $11,76 \%$ \\
\hline & Jumlah & & 34 & $100 \%$
\end{tabular}

Sumber: (Data diolah)

Tabel 2 menunjukkan data kemampuan akhir kelompok eksperiment setelah diberi perlakuan pembelajaran modul pada saat kegiatan belajar mengajar mata pelajaran akuntansi. Siswa yang memperoleh kriteria baik sekali adalah 19 siswa dengan prosentase 55,88\%, 9 siswa memperoleh kriteria baik dengan prosentase $26,47 \%, 5$ siswa memperoleh kriteria cukup dengan prosentase $14,70 \%, 0$ siswa memperoleh kriteria kurang dengan prosentase $0,00 \%$, serta 1 siswa memperoleh kriteria kurang sekali dengan prosentase $2,94 \%$.

Tabel 2. Deskripsi data kemampuan akhir kelompok eksperimen

\begin{tabular}{lllll}
\hline No. & Kriteria & Interval & Frekuensi & Prosentase \\
\hline 1. & Baik sekali & $89-100$ & 19 & $55,88 \%$ \\
2. & Baik & $78-88$ & 9 & $26,47 \%$ \\
3. & Cukup & $67-77$ & 5 & $14,70 \%$ \\
4. & Kurang & $56-66$ & 0 & $0,00 \%$ \\
5. & Kurang sekali & $45-55$ & 1 & $2,94 \%$ \\
\hline & Jumlah & 34 & $100 \%$ \\
\hline
\end{tabular}

Sumber: (Data diolah) 
Berdasarkan tabel 3 dapat diketahui bahwa 28 siswa yang tuntas belajar dengan prosentase $82 \%$. Sedangkan siswa yang belum tuntas belajar ada 6 siswa dengan prosentase $18 \%$. Total skor yang didapat dari penilaian sikap kelompok eksperimen adalah 2946. Dengan demikian nilai rata-rata kelompok eksperimen adalah 86,64 .

Tabel 3. Deskripsi Data Penilaian Sikap Kelompok Eksperimen

\begin{tabular}{|l|l|l|}
\hline Keterangan & Jumlah siswa & Prosentase \\
\hline Jumlah siswa yang tuntas belajar & 28 & $82 \%$ \\
\hline Jumlah siswa yang belum tuntas belajar & 6 & $18 \%$ \\
\hline Total siswa & 34 & $100 \%$ \\
\hline
\end{tabular}

Sumber: (Data diolah)

Tabel 4 menunjukkan data kemampuan awal kelompok kontrol, siswa yang memperoleh kriteria baik sekali adalah 1 siswa dengan prosentase 2,94\%, 3 siswa memperoleh kriteria baik dengan prosentase 8,82\%, 13 siswa memperoleh kriteria cukup dengan prosentase 38,24\%, 12 siswa memperoleh kriteria kurang dengan prosentase $35,29 \%$, serta 5 siswa memperoleh kriteria kurang sekali dengan prosentase $14,71 \%$.

Tabel 4. Deskripsi data kemampuan awal kelompok kontrol

\begin{tabular}{lllll}
\hline No. & Kriteria & Interval & Frekuensi & Prosentase \\
\hline 1. & Baik sekali & $89-100$ & 1 & $2,94 \%$ \\
2. & Baik & $78-88$ & 3 & $8,82 \%$ \\
3. & Cukup & $67-77$ & 13 & $38,24 \%$ \\
4. & Kurang & $56-66$ & 12 & $35,29 \%$ \\
5. & Kurang sekali & $45-55$ & 5 & $14,71 \%$ \\
\hline
\end{tabular}

Sumber: (Data diolah)

Tabel 5 menunjukkan data kemampuan akhir kelompok kontrol, siswa yang memperoleh kriteria baik sekali adalah 2 siswa dengan prosentase 5,88\%, 14 siswa memperoleh kriteria baik dengan prosentase 41,18\%, 11 siswa memperoleh kriteria cukup dengan prosentase 32,35\%, 6 siswa memperoleh kriteria kurang dengan prosentase $17,65 \%$, serta 1 siswa memperoleh kriteria kurang sekali dengan prosentase $2,94 \%$. 
Tabel 5. Deskripsi data kemampuan akhir kelompok kontrol

\begin{tabular}{lllll}
\hline No. & Kriteria & Interval & Frekuensi & Prosentase \\
\hline 1. & Baik sekali & $89-100$ & 2 & $5,88 \%$ \\
2. & Baik & $78-88$ & 14 & $41,18 \%$ \\
3. & Cukup & $67-77$ & 11 & $32,35 \%$ \\
4. & Kurang & $56-66$ & 6 & $17,65 \%$ \\
5. & Kurang sekali & $45-55$ & 1 & $2,94 \%$ \\
\hline
\end{tabular}

Sumber: (Data diolah)

Tabel 6 menunjukkan aspek sikap pada kelompok kontrol. 24 siswa tuntas belajar dengan prosentase $71 \%$. Sedangkan siswa yang belum tuntas belajar ada 10 siswa dengan prosentase $29 \%$. Total skor yang didapat dari penilaian sikap kelompok kontrol adalah 2739. Dengan demikian nilai rata-rata kelompok kontrol adalah 80,55 .

Tabel 6. Deskripsi Data Penilaian Sikap Kelompok Kontrol

\begin{tabular}{|l|l|l|}
\hline Keterangan & Jumlah siswa & Persentase \\
\hline Jumlah siswa yang tuntas belajar & 24 & $71 \%$ \\
\hline Jumlah siswa yang belum tuntas belajar & 10 & $29 \%$ \\
\hline Total siswa & 34 & $100 \%$ \\
\hline
\end{tabular}

Sumber: (Data diolah)

Tabel 7 menunjukkan hasil uji hipotesis. Berdasarkan tabel tersebut dapat disimpulkan prestasi belajar akuntansi siswa kelompok eksperimen lebih baik dari pada prestasi belajar akuntansi siswa kelompok kontrol. Rata-rata prestasi belajar siswa yang menggunakan modul (kelompok eksperimen) lebih tinggi dari pada rata-rata prestasi belajar siswa yang tidak menggunakan modul (kelompok kontrol). 
Tabel 7. Hasil Uji Beda Prestasi Belajar Siswa

t-Test: Two-Sample Assuming Equal Variances

\begin{tabular}{|l|l|l|}
\hline & postest kel_eksp & postest kel_kontrol \\
\hline Mean & 89,11764706 & 75,73529412 \\
\hline Variance & 158,2887701 & 69,89750446 \\
\hline Observations & 34 & 34 \\
\hline Pooled Variance & 114,0931373 & \\
\hline Hypothesized Mean Difference & 0 & \\
\hline Df & 66 & \\
\hline t Stat & 5,165676193 & \\
\hline t Critical & 1,668270515 & \\
\hline
\end{tabular}

Sumber: (Data diolah)

\section{Pembahasan}

Hasil penelitian mengenai pengaruh penggunaan modul terhadap prestasi belajar siswa dalam mata pelajaran akuntansi kelas XI IPS SMA Negeri 6 Malang menunjukkan adanya perbedaan antara siswa yang menggunakan modul (kelompok eksperimen) dengan siswa yang tidak menggunakan modul (kelompok kontrol). Hal ini terbukti dari hasil pengujian hipotesis dengan T-Test Dua Sampel Independen yang menunjukkan bahwa $t_{\text {hitung }}(5,166)>t_{\text {tabel }}(1,668)$ yang berarti ada perbedaan, maksudnya setelah dilaksanakan pembelajaran menggunakan modul (kelompok eksperimen) prestasi belajar siswa lebih baik daripada yang menggunakan pembelajaran konvensional (kelompok kontrol). Hal ini sesuai dengan teori yang telah diuraikan sebelumnya bahwa pembelajaran menggunakan modul dapat memberikan hasil belajar yang efektif untuk mencapai tujuan yang telah dirumuskan. Penggunaan modul memberi dampak atau pengaruh positif terhadap prestasi belajar siswa yang dapat dilihat dari hasil kemampuan akhir atau postest siswa kelas eksperimen.

Hasil dari pretest yang diberikan kepada siswa sebelum perlakuan diperoleh temuan bahwa kemampuan awal siswa antara kelompok eksperimen dan kelompok kontrol tidak jauh berbeda. Hal ini ditunjukkan dengan nilai ratarata yang diperoleh oleh kedua kelas tersebut. Kelas eksperimen mendapatkan nilai rata-rata kemampuan awal 66,76 dan kelas kontrol sebesar 66,53. Hal 
tersebut dapat terjadi karena materi yang digunakan untuk tes belum diberikan sehingga dalam pengerjaan soal siswa belum jelas dan mengerti sepenuhnya dan hanya sebatas pengetahuan awal saja.

Berdasarkan analisis data postest yang diberikan setelah perlakuan menunjukkan nilai rata-rata kemampuan akhir siswa kelompok eksperimen sebesar 89,12 dan kelompok kontrol hanya 75,74. Hal ini mengindikasikan bahwa nilai rata-rata prestasi belajar siswa kelompok eksperimen yang diajar dengan menggunakan modul lebih baik daripada kelompok kontrol yang diajar dengan menggunakan pembelajaran konvensional (ceramah dan tanya jawab).

Prestasi belajar ditinjau dari aspek sikap untuk kelompok eksperimen menunjukkan bahwa siswa yang tuntas belajar sebanyak 28 siswa dengan nilai rata-rata 86,64. Sedangkan untuk kelompok kontrol menunjukkan bahwa siswa yang tuntas belajar sebanyak 24 siswa dengan nilai rata-rata 80,55. Hal ini mengindikasikan bahwa prestasi belajar yang ditinjau dari aspek sikap kelompok eksperimen lebih baik daripada kelompok kontrol. Dengan demikian dapat disimpulkan bahwa prestasi belajar siswa kelas XI IPS 3 SMA Negeri 6 Malang dalam mata pelajaran akuntansi pokok bahasan jurnal penyesuaian yang diajar dengan menggunakan modul lebih baik dari siswa kelas XI IPS 4 yang diajar secara konvensional (ceramah dan tanya jawab).

Pembelajaran yang menggunakan modul dapat membantu siswa dalam pencapaian prestasi belajar yang lebih baik karena dengan menggunakan modul memberikan rangsangan dan dorongan bagi siswa untuk mempelajari bahan pelajaran dan menyelesaikan tugas yang ada dalam modul. Siswa lebih senang dan termotivasi dalam belajar menggunakan modul sehingga dapat meningkatkan prestasi belajar siswa tersebut. Hasil observasi selama penelitian menunjukkan bahwa modul yang digunakan dalam pembelajaran memang mempunyai kualitas yang baik. Modul sudah mengarah pada suatu tujuan belajar tuntas dan modul memuat petunjuk tentang apa yang harus dilakukan guru dan siswa dalam pembelajaran menggunakan modul. Materi pelajaran dalam modul juga disusun dalam suatu kerangka yang memperlihatkan kaitan dan urutan dalam bagianbagiannya sehingga memudahkan siswa untuk mempelajarinya. 
Di dalam modul yang digunakan untuk penelitian ini juga sudah memuat contoh, latihan dan kegiatan yang mendukung materi pelajaran. Selain itu proses belajar mengajar dengan menggunakan modul, interaksi antara guru dan siswa berjalan dengan baik, hal ini dapat dilihat dari keaktifan siswa untuk bertanya kepada guru jika ada hal yang belum dimengerti

\section{SIMPULAN}

Hasil penelitian menunjukkan terdapat pengaruh yang signifikan penggunaan modul terhadap prestasi belajar siswa dalam mata pelajaran akuntansi di SMA Negeri 6 Malang. Keterbatasan dari penelitian ini adalah penelitian hanya dilakukan pada satu pokok bahasan saja dikarenakan adanya keterbatasan waktu penelitian. Oleh karena itu disarankan agar peneliti lain dapat melakukan penelitian tentang penggunaan modul pada materi lain atau lebih dari satu pokok bahasan dengan menambah waktu penelitian sehingga dapat diketahui keefektifan penggunaan modul untuk meningkatkan prestasi belajar siswa.

\section{DAFTAR RUJUKAN}

Mulyasa, 2002. Kurikulum Berbasis Kompetensi. Bandung: PT Remaja Rosdakarya.

Mbulu, Joseph. 2001. Pengajaran Individual. Malang: Yayasan Elang Emas.

Nasution. 1992. Berbagai Pendekatan dalam Proses Belajar dan Mengajar. Jakarta: Bumi Aksara.

Vembriarto, S.T. 1975. Pengantar Pengajaran Modul. Yogyakarta: Yayasan Pendidikan Paramita.

Setyosari, Punaji. 1991. Pengajaran Modul. Malang: Proyek Operasi dan Perawatan Fasilitas IKIP Malang. 